\title{
PALEOMAGNETISM OF A PALEOZOIC ANORTHOSITE FROM THE APPALACHIAN PIEDMONT, NORTHERN DELAWARE: POSSIBLE TECTONIC IMPLICATIONS
}

\author{
K.V. RAO and R. VAN DER VOO \\ Department of Geology and Mineralogy, University of Michigan, Ann Arbor, MI 48109 (U.S.A.)
}

Received July 24,1979

Revised version received October 1,1979

\begin{abstract}
Two components of magnetization have been observed in fourty-four samples (five sites) of the anorthosites in the Arden Pluton. One component, with $D=325^{\circ}, I=-75^{\circ}, k=32, \alpha_{95}=13.6^{\circ}$, was isolated in many samples by progressive alternating field demagnetization and in the remainder of the collection by the use of intersecting great circles of remagnetization. The corresponding pole is located at $16^{\circ} \mathrm{N}, 303^{\circ} \mathrm{E}, d p=22.7^{\circ}, d m=24.9^{\circ}$. Assuming the age of the last metamorphism (Taconic, ca. $440 \mathrm{Ma}$ ) of the Cambrian Arden Pluton to be the age of the magnetization, this pole deviates significantly from coeval poles thus far obtained from the North American craton. The preferred explanation for this deviation is that the Arden Pluton and the surrounding Piedmont rocks belonged to a different Early Paleozoic plate on the south or east side of the Iapetus Ocean, most likely the African (Gondwana) plate, and that it was transferred to the North American plate during a subsequent continental collision.
\end{abstract}

\section{Introduction}

Tests of Wilson's [1] Paleozoic assembly of the Atlantic-bordering continents have been the subject of considerable speculation [2]. In particular, the nature and causes of the Paleozoic orogenic belts have been enigmatic with different models assuming different origins for the orogenies, such as the Taconic, Acadian, and Alleghenian orogenies in eastern North America. Paleomagnetic data can be useful in constraining these models by providing paleo-latitudes and relative orientations with respect to paleo-meridians.

The lack of lithologic correlation between the Blue Ridge and Piedmont tectonometamorphic provinces (Fig. 1) is a major impediment in the construction of plate tectonic models to understand the evolution of the Appalachian Orogen. Based on the differences in coeval rock types and deformational history between the Blue Ridge and the Piedmont, Rankin [3] proposed that they belonged to the North American and African paleoplates, respectively, now sutured at the surface along the boundary between the two struc- tural provinces, namely the Brevard Zone. However, based on the COCORP data the Brevard Zone is presently interpreted as a low-angle thrust fault related to the main horizontal fault that runs beneath the Appalachians [4]. Although much has been learned about the complex orogenic evolution of the Piedmont in recent years [5], it still remains one of the puzzling areas with poorly known geological relationships. Intense deformation and often high-grade metamorphism, a relative sparsity of fossils [6], and lack of reliable radiometric dating of tectonic and metamorphic events, are some of the uncertainties in the Piedmont crystalline belts, although recently attempts have been made to learn more about the chronology of metamorphic events, particularly in the southern Piedmont [7-9]. Moreover, available geological information is insufficient to demonstrate whether the Pjedmont is largely ensialic [10] or ensimatic [7,11]. Paleomagnetic data are presently unavailable for the Piedmont, in contrast to other structural provinces such as the Valley and Ridge Province, and constraints on various plate tectonic models [12] are lacking. For this reason, a paleomag- 
netic study was undertaken of the Arden Pluton in the northern Piedmont Province of the central Appalachians.

\section{Geology of the Arden Pluton and age of metamor- phism}

The present study area lies within the Wilmington Complex which is located in the Piedmont of northern Delaware (Fig. 1); the geology of that area is described in more detail elsewhere $[13,14]$. The overall complex has been subjected to high grade granulite-facies metamorphism with an age of about 440 $\mathrm{Ma}$, based on $\mathrm{U} / \mathrm{Pb}$ isotopic analyses of zircon fractions from the banded gneisses of the Wilmington Complex [15]. A Rb/Sr whole-rock isochron age [16] of $502 \pm 20 \mathrm{Ma}$ for the Arden Pluton within this complex has been interpreted as the age of primary crystallization, whereas an age of $440 \mathrm{Ma}$ from $\mathrm{Rb}-\mathrm{Sr}$ data for mineral separates [16] is compatible with a Taconic-aged metamorphism. The rock types in the massive, generally unfoliated pluton range from charnockite to norite to anorthosite, which is interpreted [14] as representing co-magmatic members of a suite

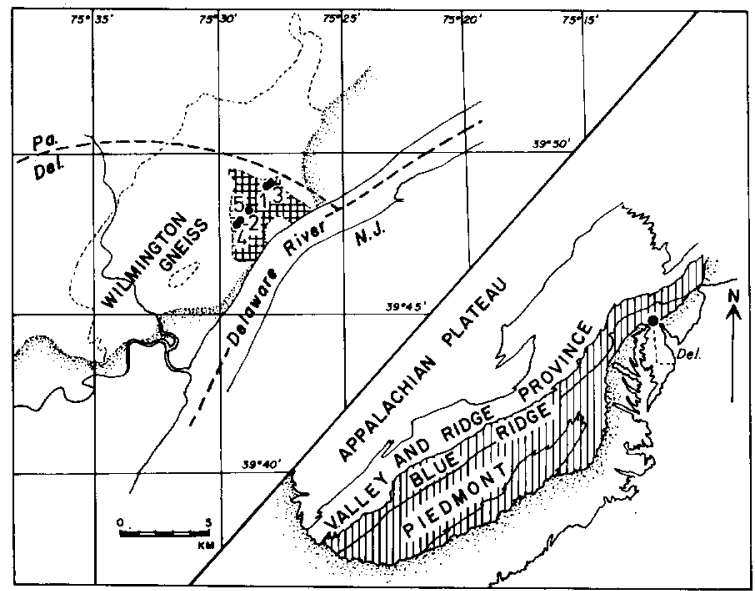

Fig. 1. Map of the Arden Pluton with the sampling sites and geological boundaries, after Ward [13]. On the right, the regional tectonic setting of the Delaware Piedmont in the Appalachians is shown; the stippled margin shows the onlap of the post-Paleozoic coastal-plain sediments. The five sampling sites in the Arden Pluton are all along the BaltimoreOhio railroad (not shown). of primary igneous rocks. The 440 Ma old metamorphism is consistent with earlier findings by Grauert and Wagner [15], who proposed this event as the evidence for the existence of a regional Taconic metamorphism in the Piedmont of Pennsylvania, Delaware, and Maryland. In general, this area has not produced any evidence for significant high-grade metamorphic events of younger age. K/Ar data [17] on biotites and micas give ages ranging from 365 to 590 Ma, but since there is no support for an Acadian metamorphism (ca. 360-390 Ma) in this region, the occasional younger ages in this range seem to have no significance. Prompted by the evidence for the Taconic, high-grade metamorphic event, we undertook the present investigation to infer a Late Ordovician pole.

\section{Paleomagnetic results from the anorthosite}

At five sites, a total of fifty-five oriented drill-core samples were collected from the anorthosites of the Arden Pluton $\left(40^{\circ} \mathrm{N}, 73.5^{\circ} \mathrm{W}\right)$. Measurements of magnetization were made with a Schonstedt SSM 1-A spinner magnetometer for two specimens from each sample; the directions of the natural remanent magnetizations (NRM's) are characterized by shallow to intermediate downward inclinations and a widespread range of declinations, but with pronounced deviations from the present-day geomagnetic field directions, promising that the samples would be paleomagnetically suitable. The magnetic intensities of the samples range two orders of magnitude, from $3.3 \mathrm{~A} \mathrm{~m}^{-1}$ to $2.9 \times 10^{-2} \mathrm{~A} \mathrm{~m}^{-1}$, rather typical of variably metamorphosed rocks.

Pilot alternating field (AF) and thermal demagnetization of the samples involved standard procedures of stepwise demagnetization with Schonstedt equipment and subsequent analysis with vector diagrams. While for eleven samples pilot thermal demagnetization or combined AF (up to $30 \mathrm{mT}$ ) plus subsequent thermal treatment did not yield stable end points of magnetization, AF demagnetization alone up to 100 $\mathrm{mT}$ was found to be successful in isolating characteristic directions of magnetization in many of the remaining 44 samples. The directions of more than 95\% of these samples change from initially down, to steeply upward inclinations in AF treatment between 


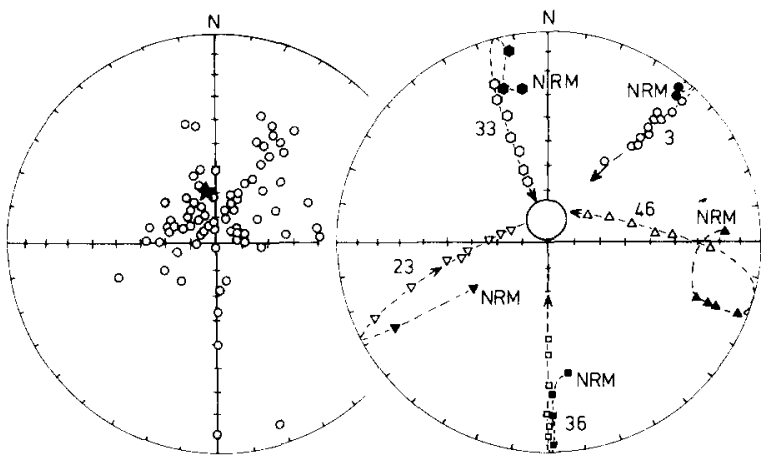

Fig. 2. Equal-area projections with the terminal directions obtained from alternating field demagnetizations of 76 specimens (left) and the remagnetization circles obtained from $A F$ demagnetization of five specimens from five different sites (right). Open symbols represent upper hemisphere projections, closed symbols represent lower hemisphere projections. The star is the present-day geomagnetic field direction, the large open circle is the convergence area for $70 \%$ of all remagnetization circles.

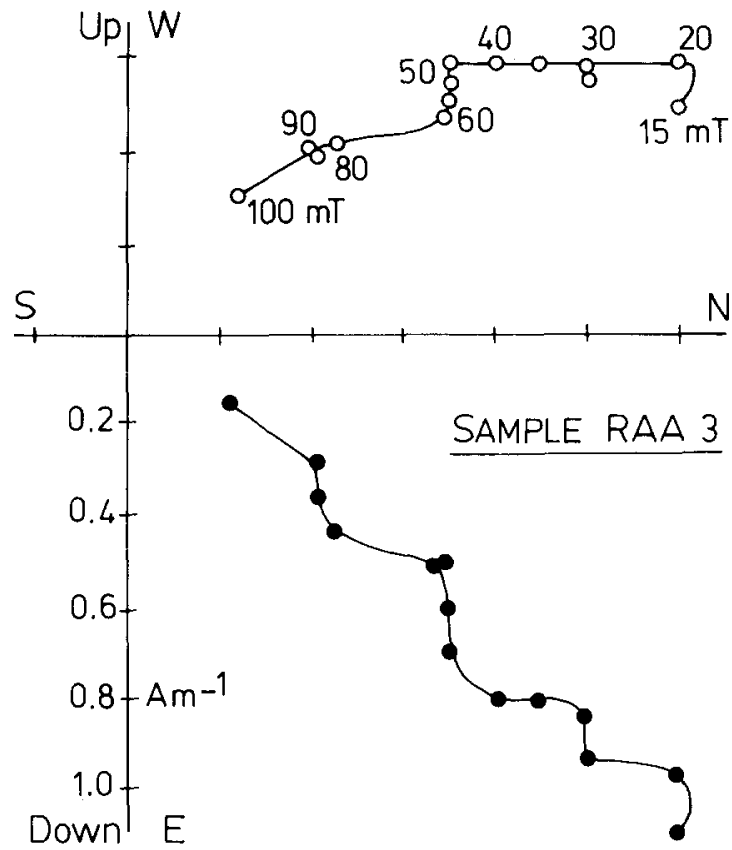

Fig. 3. Orthogonal demagnetization vector diagram [41] of the successive end points of the magnetization vector during progressive AF demagnetization of a sample from site 1 . Solid circles represent projections on the horizontal plane, open circles those on the north-south vertical plane.
10 and $70 \mathrm{mT}$ (Fig. 2, left). However, for many of the samples the corresponding vector diagrams show a typical progressive shift in direction and decay in intensity without quite reaching a stable end point, even in fields as high as $100 \mathrm{mT}$ (Fig. 3). To determine whether the terminal directions of the AF demagnetization treatment represent true end-point directions, intersections of great circles were investigated for eighteen pilot specimens, following the method of Halls [18]. Since the great circles appeared to differ largely in their azimuths, the method of convergent remagnetization circles appeared to be a promising tool to separate the high-negative inclination directions from the more dispersed lower-coercivity directions of magnetization present in the anorthosites. The success of this method depends on a convergence of remagnetization circles, arising from a difference in component dispersion, while during stepwise demagnetization the great-circle path of directional change reflects the removal of one of the two components, more than the other. The convergence point can be obtained by least-squares techniques and yields an estimate of the mean direction of the less-dispersed component. An estimate of the quality of the leastsquares fit can be ascertained by a dimensionless parameter called the quality factor, $Q$, which ranges from 0 to 1 , with the smaller values of $Q$ indicating better fits [19]. Three factors, comprising a large number of data points, low scatter of points about the great circle, and a long great-circle pathlength defined by measured points, combine to decrease the value of $Q[19]$.

A majority of the sample remagnetization circles in the present analysis has $Q$-values of less than $10^{-5}$ indicating excellent least-square fits. Progressively steeper upward directions from each specimen during the demagnetization runs, and typical sample remagnetization circles from different sites are shown along with a common area of convergence applicable to more than $70 \%$ of the specimens in this study (Fig. 2, right). It is apparent from Fig. 2 that there is a striking convergence towards a direction with a very steep upward inclination. Routine AF demagnetization of the remainder of the collection, at 30-, 50and $75-\mathrm{mT}$ steps, yielded corresponding results. Mean directions of magnetization have been calculated from the terminal directions obtained during $\mathrm{AF}$ demagnetization, using Fisher's [20] statistics (Table 
TABLE 1

Summary of paleomagnetic data from the Arden Pluton

\begin{tabular}{llrrrrrl}
\hline Site & Method & $N$ & $n$ & Decl/incl & $k$ & $\alpha_{95}$ & Pole position \\
\hline 1 & remagnetization circles & 15 & 22 & $25.3 /-73.5$ & & & $11.5^{\circ} \mathrm{N}, 86.4^{\circ} \mathrm{W}$ \\
& end-point directions & 15 & 25 & $31.1 /-55.5$ & 14 & 7.8 & \\
2 & remagnetization circles & 5 & 6 & $264.6 /-66.9$ & & & $32.4^{\circ} \mathrm{N}, 23.6^{\circ} \mathrm{W}$ \\
& end-point directions & 5 & 9 & $180.1 /-75.9$ & 6 & 23.5 & \\
3 & remagnetization circles & 8 & 11 & $321.7 /-63.8$ & & & $2.0^{\circ} \mathrm{N}, 47.7^{\circ} \mathrm{W}$ \\
& end-point directions & 8 & 14 & $350.9 /-71.1$ & 12 & 12.0 & \\
4 & remagnetization circles & 5 & 7 & $329.1 /-73.2$ & & & $12.0^{\circ} \mathrm{N}, 57.7^{\circ} \mathrm{W}$ \\
5 & end-point directions & 5 & 8 & $275.0 /-72.5$ & 8 & 21.1 & \\
& remagnetization circles & 11 & 16 & $348.6 /-78.6$ & & & $18.4^{\circ} \mathrm{N}, 69.0^{\circ} \mathrm{W}$ \\
Mean & end-point directions & 11 & 20 & $73.4 /-84.9$ & 5 & 15.9 & \\
Mean & site remagnetization circles & 5 & & $324.6 /-75.2$ & 32 & 13.6 & $16.2^{\circ} \mathrm{N}, 56.9^{\circ} \mathrm{W}$ \\
Mean & site-means (end points) & 5 & & $2.5 /-82.5$ & 15 & 20.6 & $25.3^{\circ} \mathrm{N}, 74.2^{\circ} \mathrm{W}$ \\
\hline
\end{tabular}

$N$ is the number of samples and $n$ is the number of specimens used for the analysis of the AF demagnetization (eleven thermally treated samples are not included); the number of specimens differs for different treatments since not all specimens gave data of high enough quality for the remagnetization circle method; Decl/incl are the declination and inclination in degrees; $k$ and $\alpha_{95}$ are the statistical parameters associated with the mean directions [20], giving unit weight to samples.

1). The convergence points (intersection points) of the remagnetization circles have also been calculated for each site, so that the two methods can be directly compared, although the number of specimens varies slightly because not all specimens gave data of high enough quality for the remagnetization circle method. The overall mean direction was then computed from the five site-mean directions, obtained by the two methods, as well as from all seventy-six specimen directions (Table 1). It can be seen in the table that the three overall mean directions differ by only a few degrees, and all three fall within the area of convergence shown in Fig. 2. The observed dispersion of site-mean directions is not unreasonable for plutonic rocks subjected to high-grade metamorphism.

Normalized intensity decay curves for the AF treatment indicate that most of the samples decay to one-tenth of the NRM intensity between 10 and 40 $\mathrm{mT}$, while the direction changed to progressively steeper upward inclinations. The thermal decay curves are of distributive type with one-tenth of the initial NRM intensity remaining around $500^{\circ} \mathrm{C}$ and with most blocking temperatures ranging between $450^{\circ}$ and $550^{\circ} \mathrm{C}$, but generally with a less-pro- nounced change in direction of magnetization. One can infer from this that magnetite is the predominant carrier of the magnetization, which is further confirmed by optical examination of polished thin sections from four different samples showing abundant jsolated coarse-grained magnetite as well as finegrained magnetites as inclusions in feldspars.

\section{Paleomagnetic pole position and its significance}

From the site-convergence points a mean direction of magnetization has been obtained, with declination $(D)=324.6^{\circ}$, inclination $(I)=-75.2^{\circ}, k=32$ and $\alpha_{95}=13.6^{\circ}$, yielding a pole position at $16^{\circ} \mathrm{N}, 303^{\circ} \mathrm{E}$, $d p=22.7, d m=24.9^{\circ}$. This pole is far displaced from all reliable North American Ordovician (south-)poles from the Valley and Ridge Province of the Appalachians and from the craton, and is significantly different despite the large oval of $95 \%$ confidence.

Before turning to tectonic explanations for this deviation of the Arden pole, it is necessary to discuss the reliability of the age and the position of the pole. The ambiguity that can accompany $\mathrm{Rb} / \mathrm{Sr}$ whole-rock 
ages of meta-igneous bodies, when the isochron has been significantly reset by metamorphism, is unlikely to play a role in this case, because Late Ordovician (Taconic) ages are found in many studies of the Piedmont [5,7-10,15,21-23]. Foland and Muessig [16] rule out this possibility on the basis of the size and number of samples analyzed, their dry assemblages, and substantial Sr concentrations. In addition to the supporting evidence for the Late Ordovician metamorphic age of the surrounding $b$ anded gneisses of the Wilmington Complex [18], a distinct metamorphic event has been reported for the Baltimore Gneiss of southeastern Pennsylvania, just $25 \mathrm{~km}$ to the north of the Arden Pluton [21]. A younger amphibolitefacies recrystallization event occurred at about $425-$ 460 m.y. ago, having produced garnet coronas around ferromagnesian minerals in granulites, diabase dikes, and in a $1000 \mathrm{~m}$.y. old ("Grenville") granulite-facies complex. Further support is found in the existence of a Taconic thermal event in the Pennsylvania Piedmont $[22,23]$. It is quite unlikely that the last metamorphism of the Arden Pluton has been much earlier than about $440 \mathrm{~m}$.y. ago, or that there is an uncertainty in the $\mathrm{Rb} / \mathrm{Sr}$ dating.

The statistical fact that most of the North American anorthosite bodies are Precambrian in age also does not reflect on the metamorphic age, assumed to be the age of magnetization. Other occurrences of Paleozoic anorthosites have recently been reported [24], moreover.

A tilting of the Arden Pluton cannot be entirely discounted. To reconcile the observed directions of magnetization with those expected for the area by extrapolation from the craton, a due-south tilt of about $40^{\circ}$ is required. However, most of the structural trends in this area are northeast-southwest, and a tilt along this most likely axis would produce quite different directions than the ones observed. Further paleomagnetic studies are planned to test whether the observed Late Ordovician directions are representative of the entire Maryland-southern Pennsylvania Piedmont, in which case a significant tilting could be ruled out.

Assuming, therefore, that the magnetization is about 440 m.y. old and represents the Late Ordovician paleomagnetic field, the deviation of the pole position from those of coeval rocks of cratonic North America must be explained by tectonic mechanisms on a larger scale. The deviation can, for instance, be explained in terms of a paleolatitude of the sampling site which is much more southerly than expected by more than $40^{\circ}$, with the area representing a northward displaced terrane on the west side of the Lower Paleozoic Iapetus Ocean, while retaining its North American affinity. Alternatively, the discordance can be reconciled in terms of Paleozoic paleogeography by assuming that the Arden Pluton and probably the surrounding part of the Piedmont Province belonged to a different Early Paleozoic plate on the (south-)eastern side of the Iapetus Ocean, with the North American Ordovician poles (Table 2) representing the other (northwestern) continental margin of Iapetus. The latter explanation would be in accord with Wilson's [1] original proposal, as well as with recent interpretations [25] of Silurian paleomagnetic data $[26,27]$ from New Brunswick and central Newfoundland.

TABLE 2

Late Ordovician paleomagnetic poles

\begin{tabular}{llll}
\hline Formation name and location & Pole position & Reference \\
\hline B & Beemerville, New Jersey & $35^{\circ} \mathrm{N}, 126^{\circ} \mathrm{E}$ & {$[40$, table 4, pole 6] } \\
J & Juniata, Valley and Ridge & $32^{\circ} \mathrm{N}, 114^{\circ} \mathrm{E}$ & {$[40$, table 4, pole 7] } \\
CR & Chapman Ridge, Tennessee & $27^{\circ} \mathrm{N}, 112^{\circ} \mathrm{E}$ & {$[40$, table 4] } \\
T & Trenton limestone, New York & $36^{\circ} \mathrm{N}, 116^{\circ} \mathrm{E}$ & {$[40$, table 4, pole 5] } \\
MB & Moccasin/Bays, Tennessee & $33^{\circ} \mathrm{N}, 147^{\circ} \mathrm{E}$ & {$[40$, table 4] } \\
& Mean British pole (relocated) & $7^{\circ} \mathrm{N}, 149^{\circ} \mathrm{E}$ & {$[38,39]$} \\
& Arden Pluton & $16^{\circ} \mathrm{S}, 123^{\circ} \mathrm{E}$ & this study \\
\hline
\end{tabular}

\footnotetext{
* Relocated after correcting for Mesozoic opening of the present Atlantic about Bullard's pivot [30].
} 
Based on Devonian paleomagnetic data, it has been proposed $[28,29]$ that the New England-Canadian Maritime region was located $20^{\circ}$ to the south of its present position relative to cratonic North America, during Devonian and Early Carboniferous times. Although it may be possible that the Delaware Piedmont is a southward continuation of this displaced terrane which was even farther south during Late Ordovician times, we note that at paleolatitudes $40^{\circ}$ more southerly than those for the craton, there is no likely continental American landmass to which our area can be attached.

The other, more plausible possibility is that the area under study has either a proto-European or proto-African Paleozoic affinity and that it formed a terrane transferred from one plate to another during a Wilson cycle. It is worthwhile to note that the Arden Pluton direction is much steeper than the direction extrapolated from the British mean Ordovician pole (Table 2), relocated by correcting for the Mesozoic opening of the present Atlantic Ocean [30]. It has been proposed that the North American Appalachian-Caledonian Orogen was a narrow trough, with a mid-Paleozoic north-south transcurrent motion between the two ancient margins [31]. In this reconstruction Great Britain would be located adjacent to North America in latitudes that are more southerly by about $20^{\circ}$ during the Ordovician. The non-uniqueness in the paleomagnetic determination of paleolongitudes prevents one from ascertaining whether such a transcurrent motion was accompanied by geologically plausible east-west convergent motions of the plates, but this has no relevance to the location of the Arden pole. At any rate, the possibility that the Delaware Piedmont was of proto-European origin cannot be easily accommodated with the above two factors and with the available paleomagnetic data.

Since the Arden pole is quite divergent from both the North American and the relocated mean British Ordovician poles (Fig. 4), the possibility that the present data may agree much better if the Arden region were to belong to a proto-African (Gondwana) plate in Early Paleozoic times, appears to be the most attractive. Geological evidence suggests that the Late Precambrian to Early Paleozoic Piedmont rocks are strikingly different from the coeval rock units of the Blue Ridge and the Valley and Ridge Provinces, whereas the Piedmont has paleogeographic affini-

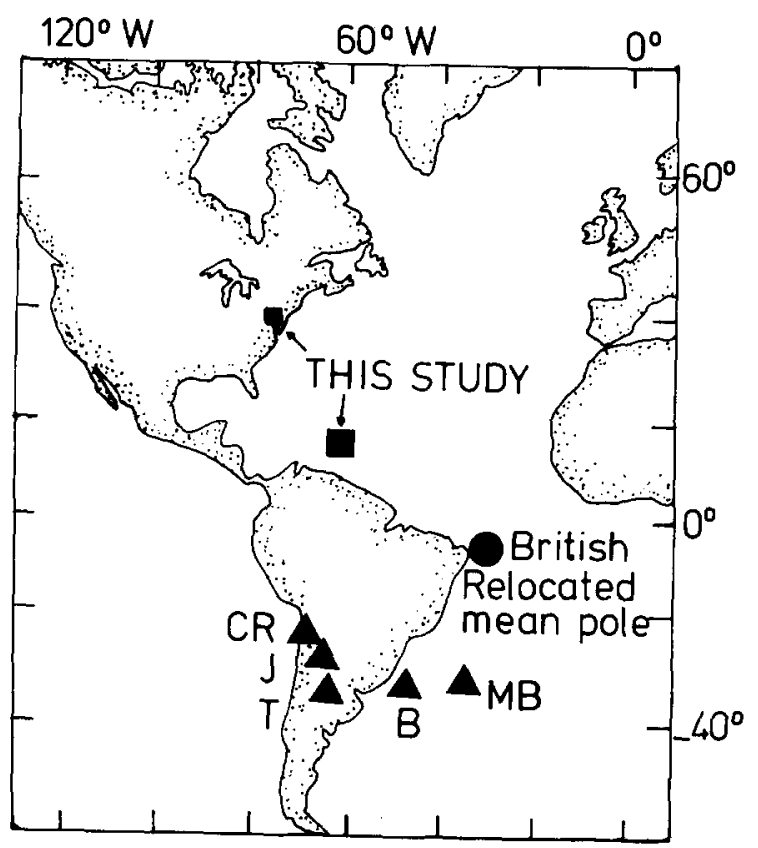

Fig. 4. Map with Late Ordovician pole positions (larger symbols) and the sampling site (small square). The pole positions are listed in Table 2 .

ties with Africa during the Early Paleozoic [4,7,8,32]. In the absence of reliable Ordovician poles for Africa [33-35], unfortunately this possibility cannot be tested paleomagnetically at the present time. However, Fig. 4 reveals that in a Pangea reconstruction the Arden pole would fall somewhere in the southern Sahara or in the equatorial west African regions, where Ordovician glaciations have been reported $[36,37]$. Future paleomagnetic investigations of Ordovician rocks from Gondwanaland, as well as from Paleozoic rock units of the Piedmont can help to resolve this reconstruction problem.

In summary, we prefer the explanation that the Delaware Piedmont did not form part of the North American plate during the Early Paleozoic, but rather belonged to a different plate, incorporating Africa and probably the rest of Gondwanaland.

\section{Acknowledgements}

We thank Drs. D.V. Wiltschko, D.R. Watts and H.N. Pollack for valuable discussions and critical read. 
ing of the manuscript. This research was supported by the Division of Earth Sciences, the National Science Foundation, grant EAR 76-14996.

\section{References}

1 J.T. Wilson, Did the Atlantic close and then re-open?, Nature 211 (1966) 676-681.

2 P. Morel and E. Irving, Tentative paleocontinental maps for the early Phanerozoic and Proterozoic, J. Geol. 86 (1978) 535-561.

3 D.W. Rankin, The continental margin of eastern North America in the South Appalachians: the opening and closing of the proto-Atlantic Ocean, Am. J. Sci. 275A (1975) 298-336.

4 F.A. Cook, D.S. Albaugh, L.D. Brown, R.D. Hatcher, S Kaufman and J.E. Oliver, Preliminary interpretation of COCORP reflection profiles across the Brevard Zone in northeast Georgia, EOS 60 (1979) 314.

5 R.D. Hatcher, Jr., Tectonics of the Western Piedmont and Blue Ridge, southern Appalachians: review and speculations, Am. J. Sci. 278 (1978) 276-304.

6 A.R. Palmer, Search for the Cambrian World, Am. Sci. 62 (1974) 216-225.

7 A.L. Odom and P.D. Fullagar, Geochronologic and tectonic relationships between the Inner Piedmont, Brevard Zone and Blue Ridge Belts, North Carolina, Am. J. Sci. 273A (1973) 133-149.

8 L. Glover, III and A.K. Sinha, The Virgilina deformation, a Late Precambrian to Early Cambrian (?) orogenic event in the central Piedmont of Virginia and North Carolina, Am. J. Sci. 273A (1973) 234-251.

9 R.D. Dallmeyer, ${ }^{40} \mathrm{Ar} /{ }^{39} \mathrm{Ar}$ incremental-release ages of hornblende and biotite across the Georgia Inner Piedmont: their bearing on Late Paleozoic-Early Mesozoic tectonothermal history, Am. J. Sci. 278 (1978) 124149.

10 R.D. Hatcher, Jr., Developmental model for the southern Appalachians, Geol. Soc. Am. Bull. 83 (1972) 2735 2760.

11 J. Rodgers, Latest Precambrian (post-Grenville) rocks of the Appalachian region, Am. J. Sci. 272 (1972) 507520.

12 B.F. Windley, The Evolving Continents (J. Wiley and Sons, New York, N.Y., 1977) 385 pp.

13 R.F. Ward, Petrology and metamorphism of the Wilmington Complex, Delaware, Pennsylvania and Maryland, Geol. Soc. Am. Bull. 70 (1959) 1425-1458.

14 A.M. Thompson, Anorthosites in the Piedmont of northern Delaware, Geol. Soc. Am. Abstr. Progr. 7 (1975) $124-125$.

15 B. Grauert and M.E. Wagner, Age of the granulite facies metamorphism of the Wilmington Complex, DelawarePennsylvania Piedmont, Am. J. Sci. 275 (1975) 683691.
16 K.A. Foland and K.W. Muessig, A Paleozoic age for some charnockite-anorthosite rocks, Geology 6 (1978) 143146.

17 K.A. Foland, Limited mobility of argon in a metamorphic terrain, Geochim. Cosmochim. Acta 43 (1979) 793801.

18 H.C. Halls, A least-squares method to find a remanence direction from converging remagnetization circles, Geophys. J.R. Astron. Soc. 45 (1976) 297-304.

19 H.C. Halls, The use of converging remagnetization circles in paleomagnetism, Phys. Earth Planet. Inter. 16 (1978) $1-11$.

20 R.A. Fisher, Dispersion on a sphere, Proc. R. Soc. London Ser. A, 217 (1953) 295-305.

21 M.E. Wagner and M.L. Crawford, Polymetamorphism of the Precambrian Baltimore Gneiss in southeastern Pennsylvania, Am. J. Sci. 275 (1975) 653-682.

22 D.M. Lapham and S.I. Root, Summary of isotopic age determinations in Pennsylvania, Penn. Geol. Surv. Inform. Circ. 70 (1971) $29 \mathrm{pp.}$

23 R.V. Amenta, Multiple deformation and metamorphism from structural analysis in the eastern Pennsylvanian Piedmont, Geol. Soc. Am. Bull. 85 (1974) 1647-1660.

24 M.D. Higgins and R. Doig, 540 m.y. old anorthosite complex in the Grenville Province of Quebec, Canada, Nature 267 (1977) 40-41.

25 E. Irving, Paleopoles and paleolatitudes of North America and speculations about displaced terranes, Can. J. Earth Sci. 16 (1979) 669-694.

26 J.L. Roy, P. Anderson and P.L. Lapointe, Paleomagnetic results from three rock units of New Brunswick and their bearing on the Lower Paleozoic tectonics of North America, Can. J. Earth Sci. 16 (1979) 1210-1227.

27 P.L. Lapointe, Paleomagnetism and orogenic history of the Botwood Group and Mount Pey ton Batholith, Central Mobile Belt, Newfoundland, Can. J. Earth Sci. 16 (1979) $866-876$.

28 D.V. Kent and N.D. Opdyke, Paleomagnetism of the Devonian Catskill Red Beds: evidence for motion of the coastal New England-Canadian Maritime region relative to cratonic North America, J. Geophys. Res. 83 (1978) 4441-4450.

29 R. Van der Voo, A.N. French and R.B. French, A paleomagnetic pole position from the folded Late Devonian Catskill Formation, and its tectonic implications, Geology 7 (1979) 345-348.

30 E.C. Bullard, J. Everett and A.G. Smith, A Symposium on continental drift, Philos. Trans. R. Soc. London, Ser. A, 258 (1965) 41-51.

31 W.A. Morris, Transcurrent motion determined paleomagnetically in the northern Appalachians and Caledonides and the Acadian Orogeny, Can. J. Earth Sci. 13 (1976) 1236-1243.

32 J. Rodgers, The eastern edge of the North American continent during the Cambrian and Early Ordovician, in: Studies of Appalachian Geology, Northern and Maritime, E-an Zen, W.A. White, J.B. Hadley and J.B. Thompson, 
eds. (Wiley-Interscience, New York, N.Y., 1968) 141 149.

33 L. Daly and J.P. Pozzi, Determination d'un nouveau pôle paléomagnétique africain sur des formations cambriennes du Maroc, Earth Planet. Sci. Lett. 34 (1977) 264-272.

34 W.A. Morris and C.M. Carmichael, Paleomagnetism of some Late Precambrian and lower Paleozoic sediments from l'Adrar de Mauritanie, West Africa, Can. J. Earth Sci. 15 (1978) 253-262.

35 D.L. Martin, A.E.M. Nairn, H.C. Noltimier, M.H. Petty and T.J. Schmitt, Paleozoic and Mesozoic paleomagnetic results from Morocco, Tectonophysics 44 (1978) 91-114.

36 R.W. Fairbridge, Early Paleozoic south pole in northwest Africa, Geol. Soc. Am. Bull. 80 (1969) 113-114.

37 L.J.G. Schermerhorn, Upper Ordovician Glaciation in Northwest Africa?, Discussion, Geol. Soc. Am. Bull. 82 (1971) 265-268.
38 J.C. Briden, W.A. Morris and J.D.A. Piper, Palaeomagnetic studies in the British Caledonides, VI. Regional and global implications, Geophys. J. Roy. Astron. Soc. 34 (1973) 107-134.

39 A.M. Faller, J.C. Briden and W.A. Morris, Palaeomagnetic results from the Borrowdale volcanic group, English Lake District, Geophys. J.R. Astron. Soc. 48 (1977) 111-121.

40 D.R. Watts and R. Van der Voo, Paleomagnetic results from the Ordovician Moccasin, Bays, and Chapman Ridge Formations of the Valley and Ridge Province, eastern Tennessee, J. Geophys. Res. 84 (1979) 645-655.

41 J.D.A. Zijderveld, AC demagnetization of rocks: analysis of results, in: Methods in Paleomagnetism, D.W. Collinson, K.M. Creer, and S.K. Runcorn, eds. (Elsevier, Amsterdam, 1967) 254-286. 